\title{
A NEW BACULOVIRUS ISOLATE THAT DOES NOT CAUSE THE LIQUEFACTION OF THE INTEGUMENT IN Spodoptera frugiperda DEAD LARVAE
}

\author{
FERNANDO HERCOS VALICENTE ${ }^{1}$, EDMAR DE SOUZA TUELHER ${ }^{2}$, CARLOS EDUARDO \\ COSTA PAIVA ${ }^{2}$, MARIA RAQUEL FELLET GUIMARÃES ${ }^{3}$, CORINA VIEIRA MACEDO $^{4}$ e JOSÉ \\ LUIS CALDAS WOLFF ${ }^{5}$
}

\author{
${ }^{1}$ Centro Nacional de Pesquisa de Milho e Sorgo/Embrapa, C.P. 151, 35700-017, Sete Lagoas, MG. \\ E-mail:valicent@cnpms.embrapa.br \\ ${ }^{2}$ Bolsistas Finep/CNPq/Fundep \\ ${ }^{3}$ Estudante de Mestrado - Universidade Federal de Viçosa - MG \\ ${ }^{4}$ Estudante de Mestrado - Universidade de Mogi das Cruzes - SP \\ ${ }^{5}$ Professor da Faculdade Presbiteriana Mackenzie - SP
}

Revista Brasileira de Milho e Sorgo, v.7, n.1, p. 77-82, 2008

\begin{abstract}
The large-scale production of Baculovirus to control fall armyworm, Spodoptera frugiperda, presents many limitations. The most important limiting factor is that the baculovirus, which infects fall armyworm, causes liquefaction of the integument immediately after death. This disruption of the integument difficultates the large scale production because dead insect must be frozen before being harvested. This fact implies in high lab work need, increasing the cost of the biopesticide. This problem was overcome by the discovery of a new baculovirus nucleopolyhedrovirus (NPV) isolate in Cascavel/PR, that doesn't cause liquefaction of the integument (isolate 6NR) immediately after the insect death. This is an extremely important factor in a large-scale baculovirus production. In addition, mortality caused by isolate 6NR on 6-day-old-larvae was above $93 \%(\mathrm{SEM}=0.7 \%)$, the average weight dead larva was $116.21 \mathrm{mg}(\mathrm{SEM}=22.9)$, the larval equivalent and weight equivalent/ha were $15.04 \mathrm{~g}$ $(\mathrm{SEM}=1.2)$ and 140.32 larvae (SEM=20.1), respectively.
\end{abstract}

Key words: Fall armyworm, large-scale production

\section{NOVO ISOLADO DE BACULOVÍRUS QUE NÃO CAUSA LIQUEFAÇÃO DO INTEGUMENTO EM LARVAS MORTAS DE Spodoptera frugiperda}

RESUMO - A produção em larga escala do baculovírus para o controle biológico da lagarta-do-cartucho, Spodoptera frugiperda, tem sérias limitações, sendo que um dos mais importantes é que os baculovírus que infectam a lagarta-do-cartucho rompem o tegumento do inseto após a sua morte. Isso dificulta a produção do baculovírus em larga escala, porque todos os insetos mortos têm que ser congelados antes de serem coletados, para depois serem formulados. Desse modo, há uma maior demanda por mão-de-obra, aumentando significativamente o custo final do produto. Este problema pode ser equacionado, uma vez que foi encontrado, em Cascavel, PR, um isolado de Nucleopoliedrovirus (NPV) que infecta a lagarta-do-cartucho e que não rompe 
(isolado 6NR) o tegumento do inseto hospedeiro imediatamente após a sua morte. Além dessa característica desejável para produção em escala comercial, a mortalidade causada pelo isolado em larvas sadias de seis dias de idade é acima de 93\% (Erro Padrão da Média $-\mathrm{EPM}=0,7 \%$ ), portanto dentro do padrão esperado. $\mathrm{O}$ peso médio das lagartas mortas foi de 116,21 mg (EPM=22,9), o número de larvas equivalentes/ha e o peso equivalente/ha foram de 15,04 g $(E P M=1.2)$ e 140,32 larvas $(E P M=20,1)$, respectivamente.

Palavras-chave: Lagarta-do-cartucho, produção em larga escala

Fall armyworm, Spodoptera frugiperda (J.E. Smith), is one of the most important maize insect pests in Brazil and its damage may reduce yield up to 52\% (Cruz et al. 1996, 1999; Figueiredo et al. 2006). The use of chemical insecticides to control S. frugiperda has increased over the years, reaching in some producing regions 10 to 14 applications to control this insect in corn (Valicente, personal observation). Valicente (1989) sampled more than 14.000 larvae from Minas Gerais State/ Brazil and a high percentage of parasitism was found in some areas, and several Baculovirus isolates, including nucleopolyhedrovirusNPV and granulovirus-GV. Valicente et al. (1989) identified a NPV infecting fall armyworm in maize fields. Valicente \& Cruz (1991) recommended isolate 18 (disrupts the integument of dead insects) to be used into the Maize Insect Pest Management (IPM) program, however large scale production has many limitations. Also, Valicente \& Costa (1995) showed that baculovirus isolate 18 was very efficient in controlling S. frugiperda in the field sprayed with irrigation water, and Cruz et al. (1997) tested rates of baculovirus in the field. Cruz et al. (2002) studied the effect of a nuclear polyhedrosis virus (isolate 18) on S. frugiperda larvae, its damage and yield of maize crop. Valicente \& Barreto (1999) reported many baculovirus isolates and parasitoids during a survey in Cascavel region, Paraná State, Brazil. The 22 Baculovirus isolates found in these two surveys compose the Baculovirus Bank belonging to the Embrapa Maize and Sorghum Research Center.

All the 22 baculovirus isolates were characterized by Barreto et al. (2005). The Spodoptera frugiperda NPV (SfNPV) isolate number 6 did not cause liquefaction of larvae integument immediately after death (6-NR) (Figure 1). This isolate was multiplicated in 6-day-old healthy larvae, under laboratory conditions, by feeding each insect with maize leaves sprayed with a viral suspension. After infection, larvae were maintained at $28^{\circ} \mathrm{C}$, and dead larvae were daily collected and stored at $-18^{\circ} \mathrm{C}$ for purification of polyhedral inclusion bodies (PIB). The same procedure was used to other isolates of the Baculovirus Bank.

The suspension was filtered through a layer of cheesecloth, and the viral filtrate suspension was centrifuged twice in a SS34 rotor at $10,000 \mathrm{rpm}$ for 15 minutes at $4^{\circ} \mathrm{C}$. Twelve microliters of TE solution (Tris- $\mathrm{HCl}$ $1 \mathrm{M}, \mathrm{pH} 8.0$, EDTA $0.5 \mathrm{M}$ ) were added to the pellet. This suspension was distributed into six centrifuge tubes containing $3 \mathrm{ml}$ of each sucrose gradient concentration $72.2 ; 70.7 ; 69.2$ and $68.8 \%$. The viral suspension was centrifuged in 

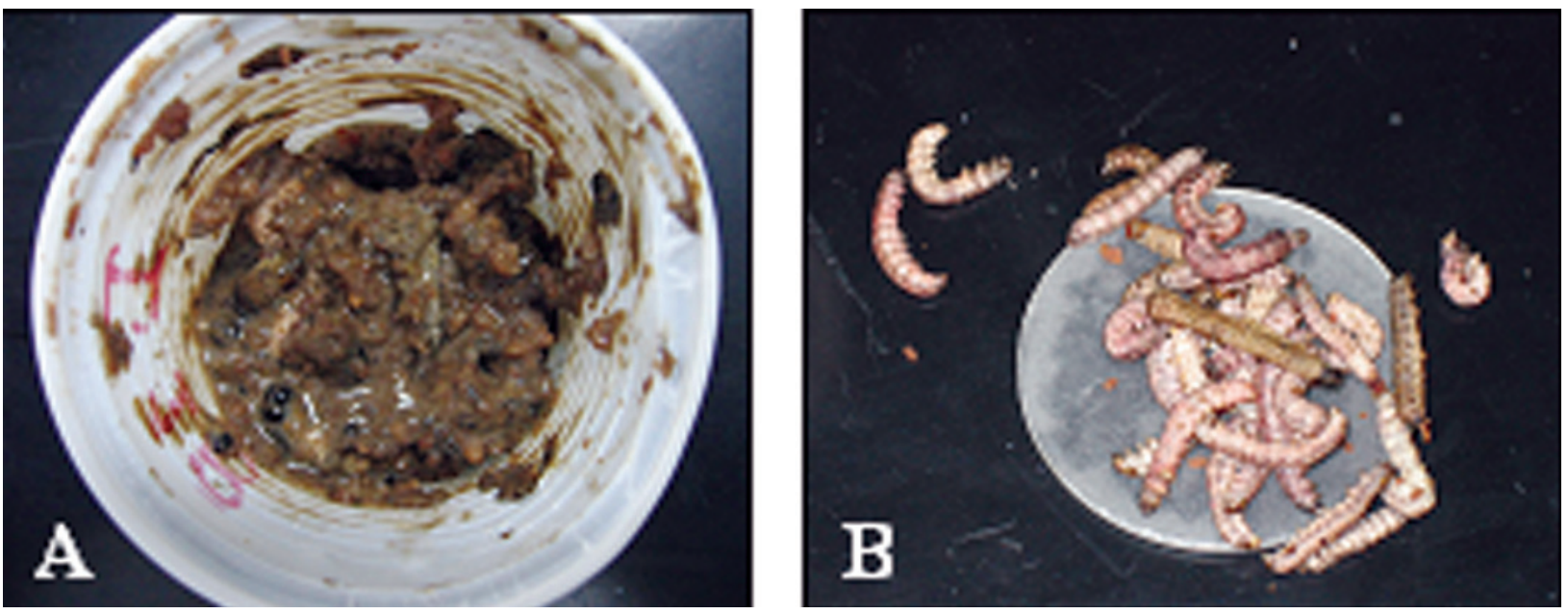

FIGURE 1 - Dead larvae of Spodoptera frugiperda after infection with S. frugiperda nucleopolyhedrovirus (SfNPV). A - isolate 18 that disrupts the insect integument after death. B- new isolate - 6NR - that does not cause liquefaction of the integument immediately after death.

an $\mathrm{AH} 627$ rotor at 24,000 rpm for 40 minutes at $4^{\circ} \mathrm{C}$. The viral band was collected and centrifuged in a SS34 rotor, and maintained at $-20^{\circ} \mathrm{C}$. This process allowed verifying viral purification standard that was documented by photos after sucrose gradient procedure.

The aspect of the isolate $6 \mathrm{NR}$ after the purification process showed some differences when compared to the common baculovirus isolates. A central and large clear viral band was present, but the band corresponding to isolate 6NR was lighter in color and consisted of a milky aspect, probably caused by higher viral concentration than in the isolate 18 . Solid impurities decanted at the bottom of the centrifuge tubes of the tested isolates; being stronger and clearer than that of the isolate 18. On the top of the viral band another band was detected, frequently composed by dirt compounds such as larval integument and gross parts of larvae. This corresponding band on isolate 6NR was clearer than in the other isolate (isolate 18) possibly due to the fact that the isolate 18 presented more gross dirties on the bottom of the tube (Figure 2).

Some studies have been done in order to understand the isolate 6NR regarding mortality, weight of infected larvae, weight equivalent/ha and larvae equivalent/ha necessary to achieve the recommended dose of $2.0 \times 10^{11} \mathrm{PIB}$ (before dilution in 250-300 liters of water/ha). Six-day-old larvae fed for 48 hours on maize (Zea mays) leaves infected with isolate 6NR and maintained at $28^{\circ} \mathrm{C}$ for $8-10$ days. Dead larvae were purified and used at $1.55 \times 10^{6}$ $\mathrm{PIB} / \mathrm{ml}$ plus Tween 20, sprayed on the maize leaves, being four replicates, with an overall use of $30 \mathrm{ml}$ per replicate. Three hundred 6day-old healthy larvae of S. frugiperda were transferred into four liters plastic recipients. The recipients were closed using a thin cloth and maintained under laboratory conditions $\left(25.0 \pm 1^{\circ} \mathrm{C}, 50.0 \pm 10 \%\right.$ r.h. and a light phase of $14 \mathrm{~h})$. 

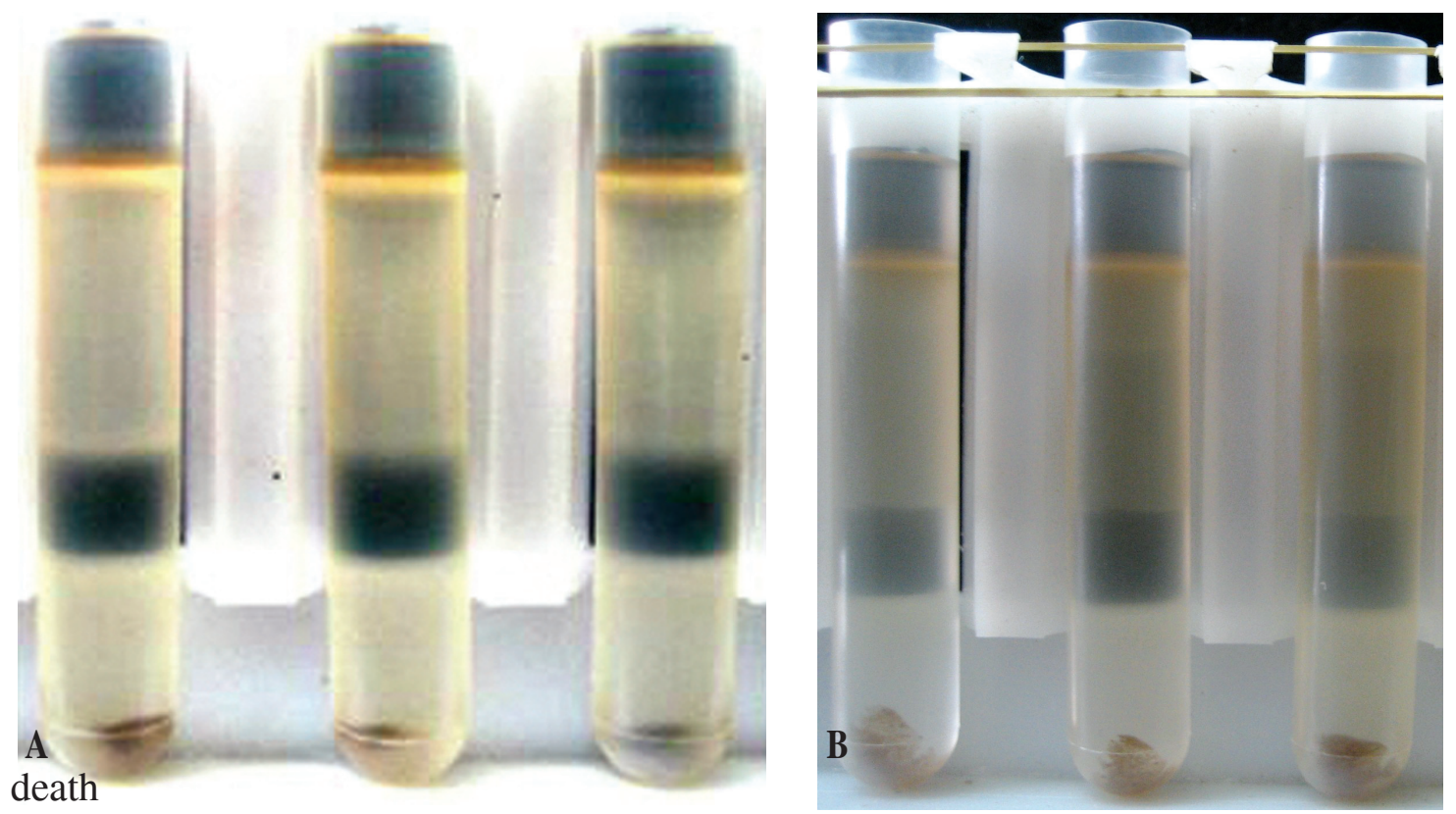

FIGURE 2- Viral bands in centrifuge tubes after sucrose gradient purification. A- isolate 6NR, that does not cause liquefaction of the larvae integument immediately after death, on the left. Bisolate 18 (disrupts the integument) on the right. From top to bottom can be identified: a sucrose band, a soft dirty ring, a baculovirus band and a sucrose plus buffer band. Gross dirt precipitate can be observed at the bottom of the tubes.

Infected larvae with typical symptoms of 6NR isolate (no liquefaction of the integument) were harvested and stored at $-18^{\circ} \mathrm{C}$ till further weighing of the larvae and counting of the PIB. Randomized groups of 20 dead larvae of each replicate were used. Each group was weighed and virus particles were extracted by maceration of dead larvae in distilled water followed by filtration through cheesecloth. After serial dilution, the number of PIBs per milliliter was quantified in a Neubauer chamber to record virus production of each sample. In order to estimate the total viral production, the average number of PIBs produced by larvae was multiplied by all the dead larvae in each replicate. The weight equivalent/ha and the larvae equivalent/ha necessary to achieve the recommended dose of $2.0 \times 10^{11} \mathrm{PIB}$ were obtained by the use of total viral production. The mortality caused by isolate $6 \mathrm{NR}$ on 6day-old-larvae was $93.43 \% \quad(\mathrm{SEM}=0.7 \%)$, a high level of efficiency that can be used in efficient production systems. Adjustments on the viral concentration to be spread at viral inoculation time have been done in order to get high mortality. The average weight of dead larvae was $116.21 \mathrm{mg}(\mathrm{SEM}=22.9)$ and larval equivalent and weight equivalent/ha were 15.04 $\mathrm{g}(\mathrm{SEM}=1.2)$ and 140.32 larvae $(\mathrm{SEM}=20.1)$, respectively. The obtained larval equivalent was much lower than the reported by Federici (1998), who describes the use of 500 larval 
equivalent/ha of S. exigua. Also, Valicente et al. (2007a and 2007b) reported that larval equivalent dropped to 100 larvae/ha when S. frugiperda was fed on Ricinus communis leaves infected with isolate $6 \mathrm{NR}$. This is due to the harvesting process, lower losses of viral particles during this process, maximizing virus yielding and consequently making the process more efficient and less laborious.

The new Brazilian 6NR isolate of S. frugiperda doesn't disrupt the integument, being very efficient to be used in a large scale baculovirus production system. Using this isolate, the larval equivalent/ha can be increased from 80 to 140 larvae/ha, corresponding to 10 and $15 \mathrm{~g} / \mathrm{ha}$, respectively. The virus preparation can be stored as a wettable powder for at least 12 months (shelf test) without loss on mortality (Valicente et al. 2007a, 2007b). Besides being efficient in killing fall armyworm, the virus is easily harvested. This is the most important factor because dead larvae don't need to be frozen before being harvested, decreasing the risk of contamination, and reducing lab labour demand for larvae manipulation, resulting in a decrease in the final cost of the biopesticide.

\section{References}

BARRETO, M. R.; GUIMARAES, C. T.; TEIXEIRA, FLÁVIA F.; PAIVA, E.; VALICENTE, F. H. Effect of Baculovirus spodoptera isolates in Spodoptera frugiperda (J.E. Smith) (Lepidoptera: Noctuidae) larvae and their characterization by RAPD. Neotropical Entomology, Londrina, v. 34, n. 1, p. 67-75, 2005.

CRUZ, I.; OLIVEIRA, L. J.; VASCONCELOS, C. A. Efeito do nível de saturação de alumínio em solo ácido sobre os danos de Spodoptera frugiperda (Smith) em milho. Anais da Sociedade Entomologica do Brasil, Londrina, v. 25, p. 293-297, 1996.

CRUZ, I.; FIGUEIREDO, M. L. C.; OLIVEIRA, A C.; VASCONCELOS, C. A. Damage of Spodoptera frugiperda (Smith) in different maize genotypes cultivated in soil under three levels of aluminum saturation. International Journal of Pest Management. London, v. 45, p. 293-296, 1999.

CRUZ, I.; FIGUEIREDO, M. L. C.; VALICENTE, F. H.; OLIVEIRA, A C. Application rate trials with a nuclear polyhedrosis virus to control Spodoptera frugiperda (Smith) on maize. Anais da Sociedade Entomologica do Brasil, Londrina, v. 26, n. 1, p. 145-152, 1997.

CRUZ, I.; GONÇALVES, E. P.; FIGUEIREDO, M. L. C. Effect of a nuclear poyhedrosis virus on Spodoptera frugiperda (Smith) (Lepidoptera: Noctuidae) larvae, its damage and yield of maize crop. Revista Brasileira de Milho e Sorgo, Sete Lagoas, v. 1, n. 2, p. 20-27, 2002.

CRUZ, I.; OLIVEIRA, L. J.; VASCONCELOS, C. A. Efeito do nível de saturação de alumínio em solo ácido sobre os danos de Spodoptera frugiperda (J. E. Smith) em milho. Anais da Sociedade Entomologica do Brasil, Londrina, v. 25, p. 293-297, 1996.

FEDERICI, B. Naturally occuring baculoviruss for insect pest control. In: HALL, F. R.; MENN, J. J. (Ed.). Biopesticides: use and delivery. Totowa: Humana Press, 1998. p. 301-320. ( Methods in Biotechnology, 5) 
FIGUEIREDO, M. L. C.; MARTINS-DIAS, A. M. P.; CRUZ, I. Relação entre a lagarta do cartucho e seus agentes de controle biológico natural na produção de milho. Pesquisa Agropecuária Brasileira, Brasília, DF, v. 41, n. 12, p. 1693-1698, 2006.

VALICENTE, F. H. Levantamento dos inimigos naturais de Spodoptera frugiperda em diferentes regiões do Estado de Minas Gerais. Anais da Sociedade Entomologica do Brasil, Jaboticabal, v. 18, p.119-130, 1989.

VALICENTE, F. H.; PEIXOTO, M. J. V. V. D.; PAIVA, E.; KITAJIMA, E. W. Identificação e purificação de um vírus da poliedrose nuclear da lagarta Spodotera furgiperda (J. E. Smith) (Lepidoptera: Noctuidae). Anais da Sociedade Entomologica do Brasil, Jaboticabal, v. 18, p. $71-81,1989$. Suplemento.

VALICENTE, F. H.; COSTA, E. F. da. Contole da lagarta do cartucho, Spodoptera frugiperda, com baculovirus através da água de irrigação. Anais da Sociedade Entomologica do Brasil, Jaboticabal, v. 24, p. 61-68, 1995.

VALICENTE, F. H.; BARRETO, M. R. Levantamento dos inimigos naturais da lagartado-cartucho do milho, Spodoptera frugiperda(J. E. Smith) (Lepidoptera: Noctuidae), na região de Cascavel, PR. Anais da Sociedade Entomologica do Brasil, Jaboticabal, v. 28, p. 333-337, 1999.

VALICENTE, F. H.; TUELHER, E.; PENA, R. C.; ANDREAZZA, R.; FELLET, M. R.; MACEDO, C. V.; GITZ, A.; WOLFF, J. L. The use of Baculovirus to control fall armyworm, Spodoptera frugiperda, in Brazil. In: ANNUAL MEETING OF THE SOCIETY FOR INVERTEBRATE PATHOLOGY, 40., 2007. Quebec. Proceedings... Quebec: SIP, 2007a. p. 61.

VALICENTE, F. H.; TUELHER, E.; PENA, R. C.; ANDREAZZA, R.; FELLET, M. R.; MACEDO, C. V.; GITZ, A.; WOLFF, J. L. The use of Baculovirus to control fall armyworm, Spodoptera frugiperda, in Brazil. In: INTERNATIONAL PLANT PROTECTION CONGRESS, 16., 2007, Glasgow, Scotland. Congress proceedings. Hampshire, UK: The British Crop Production Council, 2007b. v. 2, p. 458-459.

VALICENTE, F. H.; CRUZ. I. Controle biológico da lagarta-do-cartucho, Spodoptera frugiperda, com o baculovírus. Sete Lagoas: EMBRAPA-CNPMS, 1991. 23 p. (EMBRAPACNPMS.CircularTécnica,15). 